\title{
Sedimentary History of Trace Metals Over the Past Half-Century in Songkhla Lake, Western Coast of the Gulf of Thailand: Anthropogenic Impacts and Contamination Assessment
}

OPEN ACCESS

Edited by:

Xiting Liu,

Ocean University of China, China

Reviewed by:

Xuegang $\mathrm{Li}$,

Institute of Oceanology (CAS), China

Xueshi Sun,

Fudan University, China

*Correspondence:

Shuqing Qiao

qiaoshuqing@fio.org.cn

Specialty section:

This article was submitted to

Marine Geoscience,

a section of the journal

Frontiers in Earth Science

Received: 31 August 2021

Accepted: 21 October 2021

Published: 29 November 2021

Citation:

Dong K, Qiao S, Wu B, Shi X, Chen Y,

Shan X, Liu S, Kornkanitnan N and

Khokiattiwong S (2021) Sedimentary History of Trace Metals Over the Past

Half-Century in Songkhla Lake, Western Coast of the Gulf of Thailand:

Anthropogenic Impacts and

Contamination Assessment.

Front. Earth Sci. 9:767899.

doi: 10.3389/feart.2021.767899
Ke Dong ${ }^{1}$, Shuqing Qiao ${ }^{1,2 *}$, Bin Wu ${ }^{1,2}$, Xuefa Shi ${ }^{1,2}$, Yufei Chen ${ }^{1}$, Xin Shan ${ }^{1,2}$, Shengfa Liu ${ }^{1,2}$, Narumol Kornkanitnan ${ }^{3}$ and Somkiat Khokiattiwong ${ }^{4}$

${ }^{1}$ Key Laboratory of Marine Geology and Metallogeny, First Institute of Oceanography, Ministry of Natural Resources, Qingdao, China, ${ }^{2}$ Laboratory for Marine Geology, Pilot National Laboratory for Marine Science and Technology, Qingdao, China,

${ }^{3}$ Department of Marine and Coastal Resources, Bangkok, Thailand, ${ }^{4}$ Phuket Marine Biological Center, Phuket, Thailand

Coastal lagoons are among the most vulnerable and economically significant ecosystems on Earth. Songkhla Lake, connected with the Gulf of Thailand, is the second largest lake in Southeast Asia and supports the development of the fishery, transportation, and tourism industries in southern Thailand. With increasing anthropogenic disturbances, the lake is facing acute ecological problems and further research is needed. Here, we provide 55-year record of grain size, color reflectance, magnetic susceptibility, total organic carbon, total nitrogen, and trace element (As, $\mathrm{Hg}, \mathrm{Pb}, \mathrm{Cr}, \mathrm{Ni}, \mathrm{Cu}$, and $\mathrm{Zn}$ ) concentrations of sediment core SKL8-2 collected from Songkhla Lake. These records reveal a three-stage sedimentary and input history of trace metals under anthropogenic effects: 1) From 1964 to 1982, it was a natural terrigenous input period with a relative reduction environment when the channel connecting Songkhla Lake and the Gulf of Thailand was closed. 2) Trace metal concentrations, organic carbon content, $b^{\star}$ value, and magnetic susceptibility changed abruptly in 1982. During 1982-2000, the sources of trace metals were more complex than during 1964-1982 and mainly came from urban wastewater, industrial effluent, and fishery discharge. 3) From 2000 to 2019, contamination signals of $\mathrm{Pb}, \mathrm{Hg}, \mathrm{As}, \mathrm{Zn}$, and $\mathrm{Ni}$ emerged in the first decade because of the rapid development and poor sewage treatment around nearby cities.

Keywords: lagoon, Songkhla Lake, Gulf of Thailand, modern sedimentation, anthropogenic activities, trace metal contamination

\section{INTRODUCTION}

Coastal lagoons rank among the most productive ecosystems on Earth because they provide a wide range of ecosystem services and resources (Newton et al., 2018; Velasco et al., 2018; Faremi et al., 2021). Their high ecological value encompasses flood control, groundwater recharge, prevention of seawater intrusion, facilitation of shoreline stabilization, storm protection, retention and export of sediment and nutrients, mitigation of climate change, water purification, and providing reservoirs of genetic and/or 
species biodiversity (Pérez-Ruzafa et al., 2012; Barbier, 2014; Anthony et al., 2016; Hung et al., 2020). Furthermore, lagoons are desirable areas for a variety of anthropogenic activities such as intensive aquaculture, shipping, tourism, and recreation (PérezRuzafa et al., 2007). Consequently, coastal lagoons are highly exposed to various types of contaminants including trace metals, hydrocarbons, and plastics, which result from sources that include, but are not limited to, increased discharge of domestic, municipal, and industrial effluents (Pedro et al., 2016; Sogbanmu et al., 2016; Veiga et al., 2019; Wakkaf et al., 2020; El Zrelli et al., 2021). These contaminants persist for long periods and become bioavailable to living organisms because of their potential to bioaccumulate and biomagnify through the food chain (Bryan and Langston, 1992; Zhou et al., 2008; Bakshi et al., 2018), where sediments serve as their ultimate sink (Gadkar et al., 2019; Jung et al., 2019). Given that such lagoons are only occasionally connected with the open sea, marine influence is limited, and the sedimentary record is relatively continuous and undisturbed. Lagoon sediments can therefore serve as archives of environmental changes through time (Aparecida Leite Silva and Eduardo Rezende, 2002; Liu et al., 2006; Laermanns et al., 2021).

Anthropogenic environmental contamination by trace metals began with the domestication of fire; later, the industrial revolution led to unprecedented demand for metals and an exponential increase in the intensity of metal emissions (Schmidt and Reimers, 1991; Nriagu, 1996). Songkhla Lake, a coastal lagoon, is regarded as one of the most important natural resources in southern Thailand, with fishing and aquaculture as the main economic activities. The lake provides the people of its surroundings with food, water for irrigation and domestic use, and means of transportation and recreation (Kumblad et al., 2001). Increasing human activities, including urbanization, industrialization, and agriculturalization, have led to considerable amounts of trace metal inputs, requiring urgent remediation (Ratanachai et al., 2013).

During the past three decades, a number of studies on trace metals in lacustrine sediments have been carried out in this area, revealing the spatial pattern of trace metals in Songkhla Lake (Nakinchart et al., 2006; Pradit et al., 2010). These studies have shown that canals and their vicinities were associated with abundant trace elements because of municipal, agricultural, and industrial discharges entering the lake through the canals. Furthermore, a recent study, which analyzing the concentrations of $\mathrm{As}, \mathrm{Cd}, \mathrm{Pb}$, and $\mathrm{Zn}$ in mangrove plants (leaves, roots, and bark) and sediments, revealed heavy pollution of As (Pradit et al., 2018). However, research on sedimentary trace metal history, which can help improve understanding of the influence of human activities, remains scarce. Thus, the aims of the present study were to reveal sedimentary records of trace metals in Songkhla Lake for the past several decades, evaluate the contamination status of the lake, and examine the impact of human activities.

\section{MATERIALS AND METHODS}

\section{Study Area}

Songkhla Lake (Figure 1), a coastal shallow lagoon, is located in southern Thailand $\left(7^{\circ} 08^{\prime}-50^{\prime} \mathrm{N}\right.$ and $\left.100^{\circ} 07^{\prime}-37^{\prime} \mathrm{E}\right)$ and covers an area of $1,042 \mathrm{~km}^{2}$. The lake is divided into four parts: 1) Thale Noi, a freshwater lake surrounded by freshwater swamps with a total area of $28 \mathrm{~km}^{2} ; 2$ ) an inner lake with an average depth of $2 \mathrm{~m}$ and an area of $459 \mathrm{~km}^{2}$; 3 ) a shallow middle lake with an average depth of $1 \mathrm{~m}$ and an area of $377 \mathrm{~km}^{2}$; and 4) an outer lake with a surface area of $182 \mathrm{~km}^{2}$, which is connected to the Gulf of Thailand (GoT) through a narrow channel $420 \mathrm{~m}$ wide and $9.5 \mathrm{~m}$ deep.

Songkhla Lake is dominated by a tropical monsoonal climate. The rainy season, dominated by the southwest monsoon, occurs from mid-May to almost the end of the year and is caused by warm, humid air flowing from the Indian Ocean. Then, the dry season, controlled by the northeast monsoon, is characterized by low precipitation (https://www.tmd.go.th/en/climate.php). The salinity of the water is altered by the tidal currents and varies over a wide range from nearly 0 psu in Thale Noi to 30 psu in the outer section. There are no major rivers in the area; the lake is fed by numerous small streams and man-made canals.

The lake is a vital natural resource for the people living in the surrounding provinces, Songkhla Province and Phatthalung Province, which have populations of 1.25 and 0.50 million people, respectively, as well as some parts of Nakhon $\mathrm{Si}$ Thammarat Province. It is a major fishing ground for mollusks, crustaceans, and fish and is especially used for the aquaculture of sea bass. The catchment area of the entire Songkhla Lake Basin (approximately 8,020 $\mathrm{km}^{2}$ ), besides Songkhla Lake, consists mostly of lowland rice fields, rubber plantations, and forest-covered hills (Kumblad et al., 2001).

\section{Sediment Sampling}

Five sediment cores were collected from Songkhla Lake in August 2019 (Figure 1, Table 1) using push corers. The cores were sealed after collection and stored in the repository at a temperature of $4^{\circ} \mathrm{C}$. Half of each core was preserved, and the remaining half was photographed and then subsampled at $2-\mathrm{cm}$ intervals for further analysis. In this study, we focused on sediment core SKL8-2.

\section{Laboratory Analysis}

This study is based on comprehensive analyses of color reflectance, magnetic susceptibility, grain size, total organic carbon (TOC), total nitrogen (TN), and elements concentrations of core sediment, combined with ${ }^{210} \mathrm{~Pb}$ dating chronology.

The sedimentation rate was determined using ${ }^{210} \mathrm{~Pb}$ radionuclide dating at the Radioactive Isotopes Analysis Laboratory of East China Normal University, Shanghai, China. Lyophilized samples were stored for at least 3 weeks in sealed containers to reach secular equilibrium prior to analysis. The analysis was then conducted on a well-type HPGe gamma spectroscope (GSW275L).

Sediment color and magnetic susceptibility were measured by MSCL (Multi Sensor Core Logger). In sediment color, $\mathrm{L}^{\star}$ describes the lightness between black (0) and white (100), while $\mathrm{a}^{*}$ and $\mathrm{b}^{*}$ denote the red (positive values)-green (negative values) and yellow (positive values)-blue (negative values) chromaticity, respectively. The chlorine content in the sediments was analyzed by an X-ray fluorescence (counting 


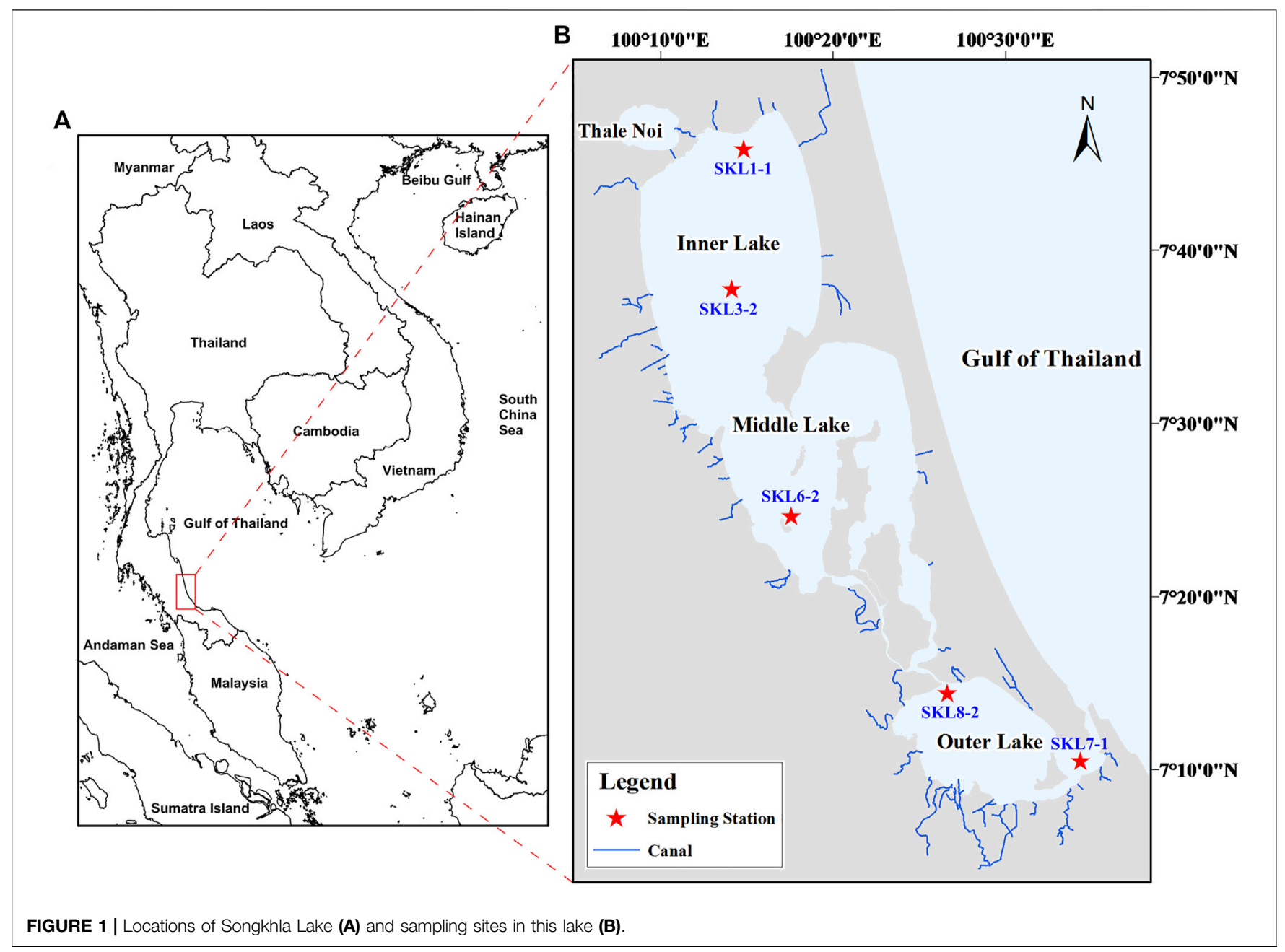

TABLE 1 | Information on five core samples from Songkhla Lake.

\begin{tabular}{lcccc}
\hline Core sample & Longitude & Latitude & Water depth $(\mathbf{m})$ & Core length $(\mathbf{c m})$ \\
\hline SKL1-1* & $100.24^{\circ} \mathrm{E}$ & $7.76^{\circ} \mathrm{N}$ & 2.0 & 88 \\
SKL3-2 & $100.23^{\circ} \mathrm{E}$ & $7.63^{\circ} \mathrm{N}$ & 2.3 & 124 \\
SKL6-2 & $100.29^{\circ} \mathrm{E}$ & $7.41^{\circ} \mathrm{N}$ & 1.0 & 52 \\
SKL7-1 & $100.56^{\circ} \mathrm{E}$ & $7.17^{\circ} \mathrm{N}$ & 0.9 & 134 \\
SKL8-2 & $100.44^{\circ} \mathrm{E}$ & $7.24^{\circ} \mathrm{N}$ & 1.4 & 102
\end{tabular}

${ }^{*} S K L$ is the abbreviation of Songkhla Lake.

intensity) core scanner (Itrax, Sweden). Grain sizes of the samples were determined with a Mastersizer 3000 instrument, and 10\% parallel samples were chosen for repeat measurement to confirm the reliability of the results. The measurement range of the instrument was $0.02-2,000 \mu \mathrm{m}$. The error based on repeated measurements was estimated as $<3 \%$.

TOC and TN were measured by a VarioEL III elemental analyzer (ELementar, Germany). During measurement, 10\% parallel samples and GSD-9 standard material were also measured, and the relative measurement error was lower than $0.5 \%$. Inductively coupled plasma optical emission spectrometry (ICP-OES, Thermo iCAP-6300, United States) was used to measure $\mathrm{Al}_{2} \mathrm{O}_{3}$ and $\mathrm{CaO}$ contents, whereas $\mathrm{Cr}$, $\mathrm{Ni}, \mathrm{Cu}, \mathrm{Zn}$, and $\mathrm{Pb}$ contents were measured by inductively coupled plasma mass spectrometry (ICP-MS, Thermo X-series II, United States). As and $\mathrm{Hg}$ were measured using atomic fluorescence spectrometry (AFS-920). Ten percent parallel samples, China Stream Sediment Standards (GBW07309, GBW07313, GBW07314, and GBW07316), and appropriate blanks were used for quality control. The relative standard deviations of the analyses were all $<5 \%$. All measurements except for radionuclides were performed at the Key Laboratory of Marine Geology and Metallogeny, Ministry of Natural Resources, China. 
TABLE 2 | ERL (effects range low) and ERM (effects range median) guideline values for trace metals $(\mu \mathrm{g} / \mathrm{g}$ in dry weight).

\begin{tabular}{lccccccc} 
& $\mathbf{C r}$ & $\mathbf{N i}$ & $\mathbf{C u}$ & $\mathbf{Z n}$ & $\mathbf{P b}$ & $\mathbf{A s}$ & $\mathbf{H g}$ \\
\hline ERL & 81 & 20.9 & 34 & 150 & 46.7 & 8.2 & 0.15 \\
ERM & 370 & 51.6 & 270 & 410 & 218 & 70 & 0.71
\end{tabular}

\section{Assessment of Trace Metal Contamination in Sediments}

To better understand the risk associated with trace metals, contamination indices, including the enrichment factor (EF) and geo-accumulation index $\left(\mathrm{I}_{\text {geo }}\right)$, and sediment quality guidelines (SQGs) were employed in the present study.

\section{Enrichment Factor of Trace Metals}

The EF is a powerful tool used to elucidate the degree of contamination in sediment in relation to the background value. The EF can be calculated according to the following function (Buat-Menard and Chesselet, 1979):

$$
\mathrm{EF}=\frac{\mathrm{S}_{\mathrm{n}} / \mathrm{S}_{\text {ref }}}{\mathrm{a}_{\mathrm{n}} / \mathrm{a}_{\mathrm{ref}}}
$$

where $S_{n}$ is the content of contaminating elements, $S_{\text {ref }}$ is the content of the reference element $\mathrm{Al}, a_{n}$ is the background content of contaminating elements, and $a_{r e f}$ is the background content of the reference element $\mathrm{Al}$.

$\mathrm{EF} \leq 1$ indicates no enrichment, $1<\mathrm{EF} \leq 3$ is minor enrichment, $3<\mathrm{EF} \leq 5$ is moderate enrichment, and $\mathrm{EF}>5$ suggests severe enrichment.

\section{Geo-Accumulation Index of Trace Metals}

The $I_{\text {geo }}$ allows evaluation of contamination by correlating the obtained current concentration of metals with their background concentrations. The $\mathrm{I}_{\text {geo }}$ values for metals were determined using the following equation (Müller, 1979):

$$
I_{\text {geo }}=\log _{2}\left(\frac{C_{n}}{K B_{n}}\right)
$$

where $C_{n}$ is the concentration of metal $\mathrm{n}$ of the sediment, $B_{n}$ is the geochemical background concentration of metal $\mathrm{n}$, and the constant $\mathrm{K}$ is generally assigned 1.5 , which is a background matrix correction factor for lithogenic effects.

As a threshold value, $I_{\text {geo }}=0$ is selected. A value of $I_{\text {geo }} \leq 0$ suggest uncontaminated, and $\mathrm{I}_{\text {geo }}>0$ are divided into six different contamination levels.

\section{Sediment Quality Assessment}

SQGs are useful to estimate biological effects in contaminated sediments (Long et al., 1995; MacDonald et al., 2000; Filgueiras et al., 2004; Hinkey and Zaidi, 2007; Violintzis et al., 2009). In this study, potential ecological effects were evaluated based on the effects range low (ERL) and effects range median (ERM) guideline values for estuarine and marine environments proposed by the United States National Oceanic and Atmospheric Administration (Table 2). The ERL represents the 10th percentile of the effects database, below which harmful effects on aquatic biota are rarely observed. In contrast, the ERM represents the 50th percentile values of the effects data and indicates concentrations above which harmful effects are often observed.

\section{RESULTS AND DISCUSSION}

\section{Sediment Chronology}

From the surface to the bottom of core sediment SKL8-2, ${ }^{210} \mathrm{~Pb}_{\mathrm{ex}}$ activity generally decreased in the pattern of a negative exponential curve, although occasional anomalies fluctuated in certain layers (Figure 2). Constant Flux Constant Sedimentation (CFCS) model was then selected to determine the sedimentation rate (Crozaz et al., 1964; Sanchez-Cabeza and Ruiz-Fernández, 2012). On the basis of ${ }^{210} \mathrm{~Pb}_{\mathrm{ex}}$ values and distinct colors from gray to yellowish brown in core photograph, dividing the SKL8-2 into two stages of sedimentation rates was justified. The bottom part $(63-102 \mathrm{~cm})$ indicated a sedimentation rate of $2.3 \pm 0.6 \mathrm{~cm} /$ year, and the upper layer of $0-63 \mathrm{~cm}$ had a lower average sedimentation rate of $1.6 \pm 0.6 \mathrm{~cm} /$ year. Therefore, this core covered a period of approximately 55 years (1964-2019).

\section{Lithology and Sedimentary Environment}

Based on the differences of sediment color, magnetic susceptibility, TOC/TN ratio, and calcium content, the core could be divided into three sections (Figure 3): 1) Section A, 63-102 cm corresponding to 1964-1982; 2) Section B, 32-63 cm,

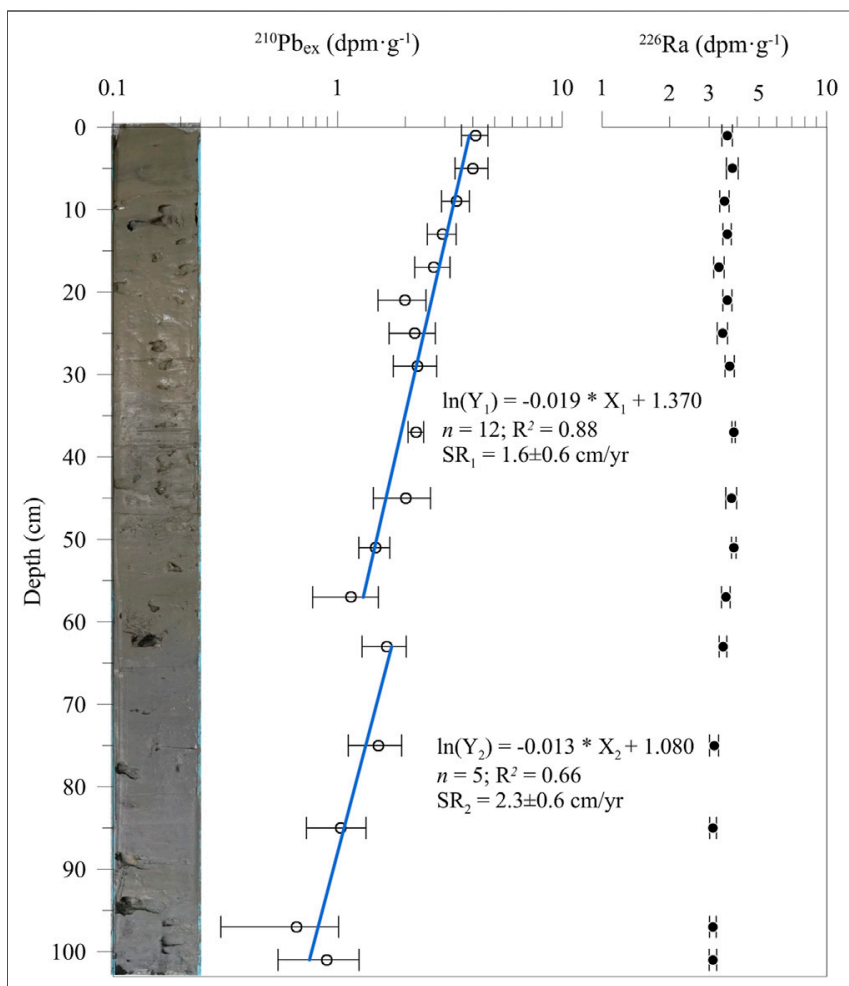

FIGURE 2 | Vertical distribution of ${ }^{210} \mathrm{~Pb}$ ex and ${ }^{226} \mathrm{Ra}$ and a photograph of sediment core SKL8-2. Depth errors are $\pm 1 \mathrm{~cm}$. The blue lines represent the linear fitting results with the detailed information on the right. 


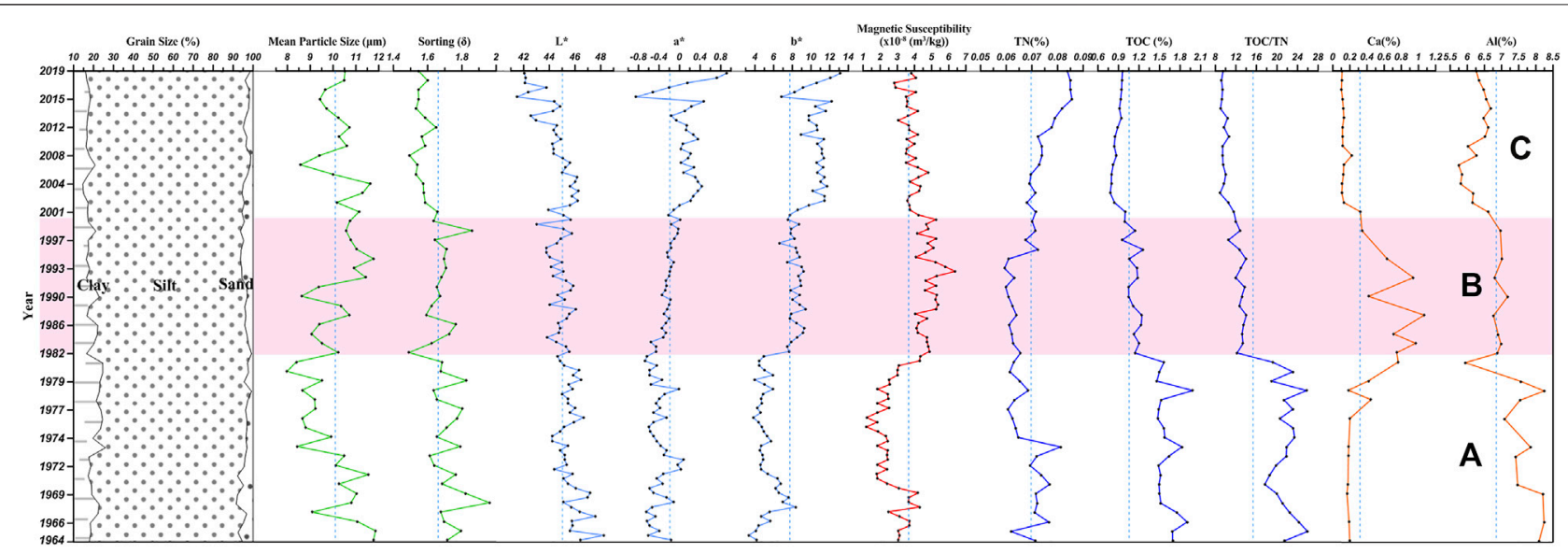

FIGURE 3 | Bulk properties of sediment core SKL8-2 collected from Songkhla Lake and its three sections, (A-C). Dashed lines represent the average values.

FIGURE4|Vertical variations of chlorine content at five stations in Songkhla Lake (distance from the channel connected with the Gulf of Thailand: SKL7-1<SKL8-2

spanning from 1982 to 2000; and 3) Section C, 0-32 cm, deposited during 2000-2019.

\section{Section A: 1964-1982}

These layers were mainly gray clayey silt with an average silt content of $74.3 \%$, followed by the clay fraction (averaging $21.3 \%$ ) and sand fraction (averaging 4.4\%). The average sorting coefficient was 1.7 , indicating poor sorting.

In this section, the sediment was characterized by high TOC content (averaging 1.5\%), and there was conspicuous tiny black carbonaceous debris at depths of 70, 73-75, 90, and 95-98 cm. The mean TOC/TN ratio was as high as 21.7 , indicating that terrestrial plants prevailed as the source of organic matter (Meyers, 1994). Given the obviously low magnetic susceptibility, $b^{\star}$ and $a^{\star}$ values, and high TOC and TN, it may be reasonable to conclude that the environment in the lake was relatively reducing (Tian et al., 2011).

The count intensity of chlorine $(\mathrm{Cl})$ was approximately 2,700 cps during 1964-1982 and increased progressively after 1982. The
$\mathrm{Cl}$ trends in sediment cores SKL7-1 and SKL6-2 were similar to that in SKL8-2 (Figure 4). The period before the rise was consistent with the closure of the GoT channel in order to develop irrigation agriculture by preventing seawater salinity invasion (ONEP, 2005). While the cores collected far away from the channel (e.g., SKL3-2 and SKL1-1) did not show a response to this increasing change of $\mathrm{Cl}$, which further proved the reconnection with the GoT at around 1982.

\section{Section B: 1982-2000}

Sediments in Section B were silty sand, slightly coarser than sediments in Section A, with the mean grain size rising from 9.6 to $10.3 \mu \mathrm{m}$. The average contents of silt, clay, and sand in this section were $76.7 \%, 19.2 \%$, and $4.1 \%$, respectively, and the sorting was poor. The mean TOC/TN ratio of 13.2 suggested mixed terrestrial and marine sources for organic matter (Meyers, 1994).

The average calcium content was $0.7 \%$, and Ca content peaked at $1.1 \%$ at around 1987 . In addition, large amounts of small shells 
and biological detritus were found in this layer, and pronounced large shells were found at $44-\mathrm{cm}$ depth. We ascribed these findings to the Thai government's proposal to expand shrimp farming in the Songkhla Lake Basin in 1987 (ONEP, 2005). Since 1987 , the area where there previously were rice plantations in Songkhla Lake Basin has been gradually occupied by shrimp ponds. Thus, accelerated shrimp breeding and seafood processing in this period boosted the growth of aquatic shelly organisms and subsequent calcareous deposition in the lake. In addition, this change may also have been caused by the increased productivity of calcareous plankton and/or benthos caused by the opening of the channel with the GoT. As previously reported, nutrients brought by marine plankton can stimulate the growth of calcareous organisms (Yu et al., 2020).

The most intriguing feature of this section was the evident transformation at the bottom interface, where the TOC content, $b^{\star}$ value, and magnetic susceptibility all abruptly changed. This was responding to the reconnection of the lake with the GoT. Under marine influence, the hydrodynamic forces in the lake were increased and part of the sediment was transported to the GoT, resulting in the decline in the deposition rate. The dropped TOC and Al contents were considered a consequence of the intensified hydrodynamics as well, rendering it more difficult for fine-grained particulate to sediment. The $b^{*}$ value and magnetic susceptibility increased over their average values, indicating a transition to an oxidizing environment (Tian et al., 2011).

\section{Section C: $\mathbf{2 0 0 0 - 2 0 1 9}$}

Sediments in the upper part of the core $(0-32 \mathrm{~cm})$ were gray clayey silt with a mean grain size of $10.2 \mu \mathrm{m}$. The average silt content was $79.5 \%$, with $17.1 \%$ and $3.4 \%$ clay and sand fractions, respectively.

TN and TOC in this section increased considerably, which was consistent with the gradual decrease of brightness. Nevertheless, the organic matter content in this layer was still low, and the average TOC/TN ratio was 9.75 , indicating that aquatic plants were the source of the organic matter (Meyers, 1997).

Ca content sharply dropped to below the average of the deeper sections (Figure 3). During this depositional period, local fishery development was contained by either enhanced eutrophication or strengthening regulation; for instance, the use of fishing tools was limited and the area of shrimp aquaculture was reduced. Analysis of satellite images from 2002 previously showed that the shrimp aquaculture area had been reduced to approximately $50.15 \mathrm{~km}^{2}$, 40.2\% less than the area in 1995 (Ratanachai et al., 2014). The implementation of environmental regulations led to the decline of nutrients in the lake, which hindered the growth of calcareous organisms and thus caused a decline in sedimentary Ca content. Because there was still marine organism communication during this period, it is reasonable to infer that the plateau of Ca content during 1982-2000 mainly resulted from shrimp farming.

\section{Temporal Variations and Sources of Trace Metals \\ Trace Metal Concentrations}

The ranges of down-core concentrations of $\mathrm{As}, \mathrm{Hg}, \mathrm{Pb}, \mathrm{Cr}, \mathrm{Ni}$, $\mathrm{Cu}$, and $\mathrm{Zn}$ were $14.82-24.34$ (mean 19.04) $\mu \mathrm{g} / \mathrm{g}, 0.039-0.048$ (mean 0.042) $\mu \mathrm{g} / \mathrm{g}, \quad 45.96-58.55 \quad$ (mean 49.61) $\mu \mathrm{g} / \mathrm{g}$, 44.11-59.93 (mean 50.05) $\mu \mathrm{g} / \mathrm{g}, 15.70-25.30$ (mean 18.96) $\mu \mathrm{g} / \mathrm{g}, 9.99-15.94$ (mean 11.63) $\mu \mathrm{g} / \mathrm{g}$, and 47.35-53.44 (mean $51.62) \mu \mathrm{g} / \mathrm{g}$, respectively (Figure 5). In general, the contents of trace metals decreased from the bottom to the top. The downward profiles of $\mathrm{Cr}, \mathrm{Ni}, \mathrm{Cu}$, and $\mathrm{Zn}$ showed similar vertical distributions. Their concentrations exhibited clear declines since 1964 despite peaking at around 1978. In 1981, the turning point year, the decline of trace metal contents slowed considerably, and the values were lower than the mean values. The concentrations of $\mathrm{As}, \mathrm{Hg}$, and $\mathrm{Pb}$ changed dramatically but presented low values since the 20th century.

As shown in Table 3, this study revealed that the levels of trace metals in Songkhla Lake were relatively high compared with those of the South China Sea shelf $(\mathrm{Cr}=39.3 \mu \mathrm{g} / \mathrm{g}, \mathrm{Cu}=$ $7.43 \mu \mathrm{g} / \mathrm{g}, \mathrm{Zn}=54.4 \mu \mathrm{g} / \mathrm{g}, \mathrm{Pb}=15.6 \mu \mathrm{g} / \mathrm{g}, \mathrm{As}=9.71 \mu \mathrm{g} / \mathrm{g}$, and $\mathrm{Hg}$ $=0.02 \mu \mathrm{g} / \mathrm{g}$ ) (Zhang and Dui, 2005). However, the concentrations of $\mathrm{Cu}, \mathrm{Zn}, \mathrm{Cr}, \mathrm{Ni}$, and $\mathrm{Hg}$, unlike those of $\mathrm{Pb}$ and As, were lower than those in Bangkok Bay (Qiao et al., 2015; Guo et al., 2019), the western GoT (Liu et al., 2016), and the western Sunda Shelf (Zhang et al., 2021). Based on those findings combined with the above results, sediments in the surrounding region of Songkhla Lake were not significantly contaminated by $\mathrm{Cu}, \mathrm{Zn}, \mathrm{Cr}$, or $\mathrm{Ni}$, while $\mathrm{As}, \mathrm{Pb}$, and $\mathrm{Hg}$ contents were at moderate contamination levels at many stations in the estuaries primarily because of anthropogenic activities.

\section{Sources of Trace Metals in Sediments}

Inter-element correlations were quantified using a correlation matrix. Principal component analysis (PCA) was performed to reduce the dimensionality of the data and determine which elements explained the most variability across the sediment core. PCA generates principal components (PCs), which are uncorrelated variables composed of linear combinations of the original variables. For each PC, a loading is assigned to each of the original variables, determined by correlation between the original variable and the PC. The correlation matrix and PCA were performed on samples from three periods to identify the source of trace metals. The results of sections $\mathrm{B}$ and $\mathrm{C}$ were similar; therefore, we combined them to obtain the outcomes exhibited in Figure 6 and Table 4.

For the entire sediment core, the first two PCs were responsible for $84 \%$ of the total variance, with $\mathrm{PC} 1$ accounting for $64 \%$ and PC2 explaining $20 \%$ of the data variance. In the PCA loading plot (Figure 6A), there are two apparent clusters of trace metals, with $\mathrm{Zn}, \mathrm{Ni}$, and $\mathrm{Cr}$ having high loadings on $\mathrm{PC} 1$ and $\mathrm{Pb}$, $\mathrm{Hg}$, and As having high loadings on PC2. Strong $(r>0.8)$ and significant $(\mathrm{p}<0.01)$ correlations between trace metals $(\mathrm{Zn}, \mathrm{Ni}$, and $\mathrm{Cr}$ ) and TOC may reflect that organic matter provided more binding sites for metals and thus metals were enriched. $\mathrm{Al}$ is generally regarded as a terrestrial proxy; thus, PC1 represented $\mathrm{Zn}, \mathrm{Ni}$, and $\mathrm{Cr}$, which are strongly regulated by organic matter and may have originated from lithogenic sources. However, $\mathrm{Pb}$, $\mathrm{Hg}$, and As, represented by PC2, were not correlated with TOC $(r<0.5)$, which may indicate an entirely different regulation 

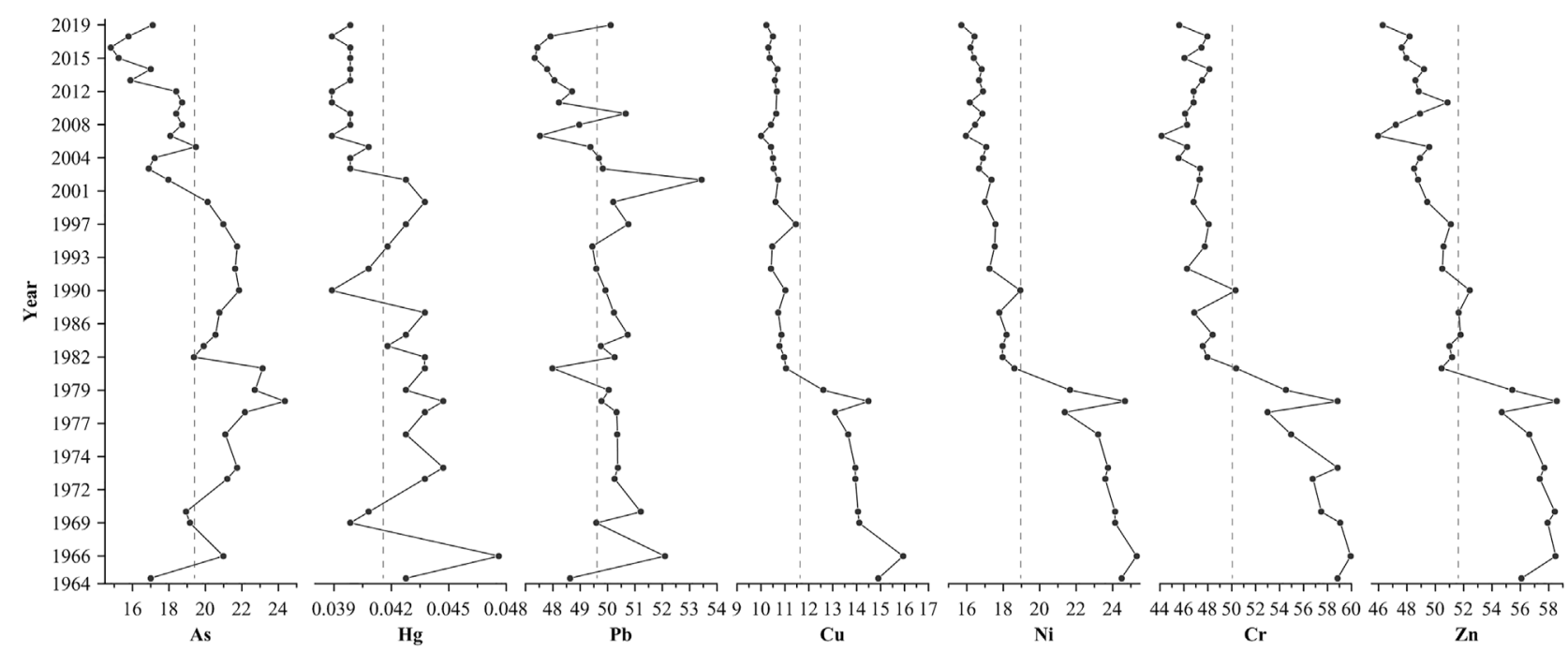

FIGURE 5 | Variation of trace metals concentrations ( $\mu \mathrm{g} / \mathrm{g}$ in dry weight) in sediment core SKL8-2 of Songkhla Lake. Dashed lines represent the average values.

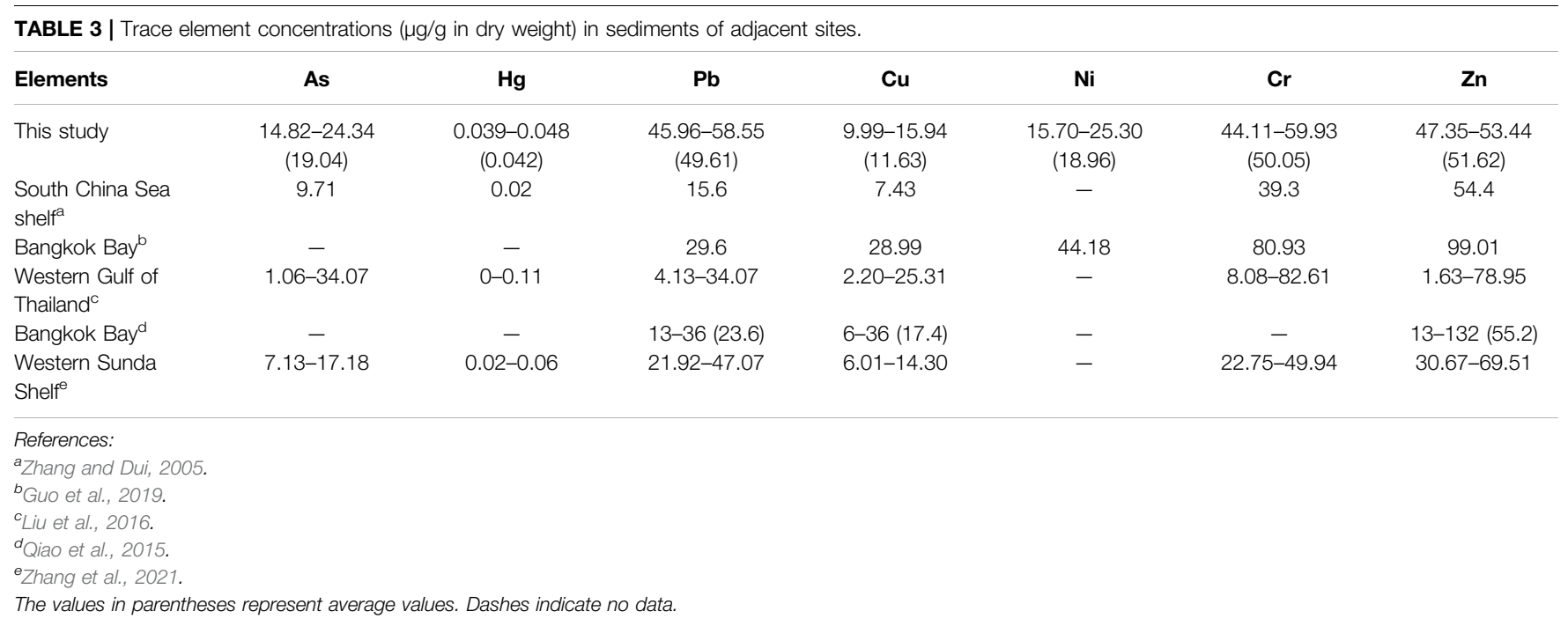

pattern from that of the other metals (Figure 6A), likely related to human actions.

Significant correlations between elements may reflect collective sources or similar influencing factors (Zaharescu et al., 2009). During the period from 1964 to 1982, TOC was significantly correlated with TN $(r=0.507 ; \mathrm{p}<0.01)$, suggesting a common origin. At the same time, significant correlations between $\mathrm{Cr}, \mathrm{Ni}, \mathrm{Cu}, \mathrm{Zn}$, and $\mathrm{Al}$, as well as high TOC/TN ratio of 21.7, jointly shed light on the proximate natural terrigenous input. Accordingly, $\mathrm{PC} 1$ of this part, which encompasses high loading of $\mathrm{Cr}, \mathrm{Ni}, \mathrm{Cu}, \mathrm{Zn}$, and $\mathrm{Al}$, accounted for $64 \%$ of the variance. PC2 is distinguished by positive loading of As, $\mathrm{Hg}$, and $\mathrm{Pb}$, indicating greater anthropogenic contribution (Figure 6B).

After 1982, aside from $\mathrm{Zn}$ and $\mathrm{Ni}$, the correlations between other indicators weakened $(r<0.5)$. This indicates that the sources of trace metals after 1982 were more complex than those before 1982 and may have resulted from the following three causes. First, rapid urban and industrial expansion with outdated waste treatment brought large amounts of effluent discharge into the lake (Pradit et al., 2013). This cause may be supported by the striking distinction of the PC loads of $\mathrm{Cu}$ and $\mathrm{As}$ after 1982 compared with those before 1982. $\mathrm{Cu}$ and As have generally been used as wood preservatives, and their material sources were closely related to the rapid development of the wood industry around Songkhla Lake in the 1990s (Sompongchaiyakul and Sirinawin, 2007). Aquaculture may have been the next most important contamination source. The Thai government's policies stimulated the development of aquaculture starting in 1987. The use of fishing gear and tackle, fertilizer application, food processing, and ultimately transportation may account for the contamination of the lake (Ratanachai et al., 2014). Furthermore, 
A the whole sedinent core

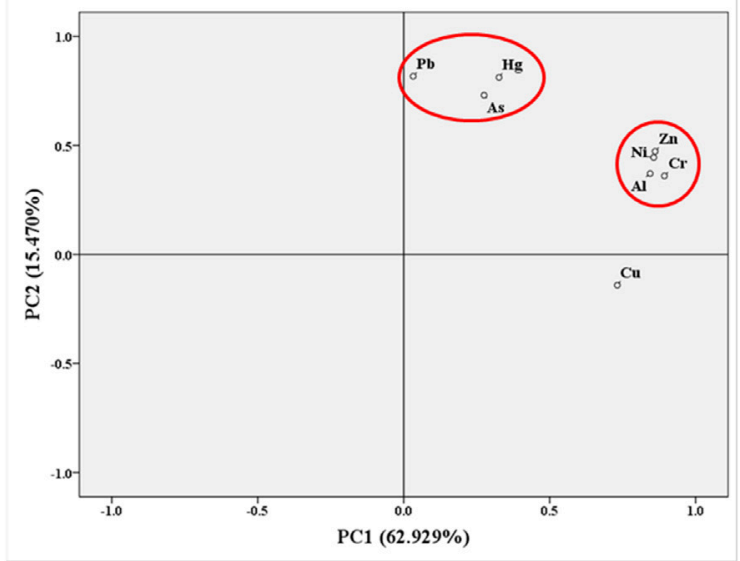

B 63-102cm of sediment core (1964-1982)

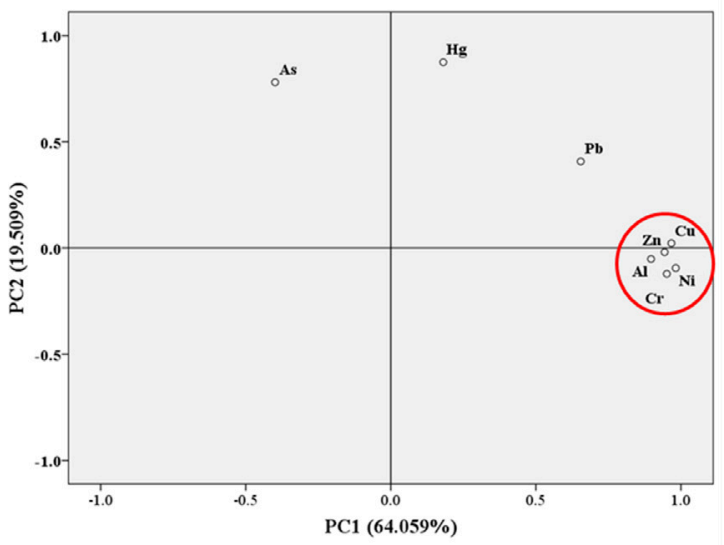

C $0-63 \mathrm{~cm}$ of sedinent core (1982-2019)

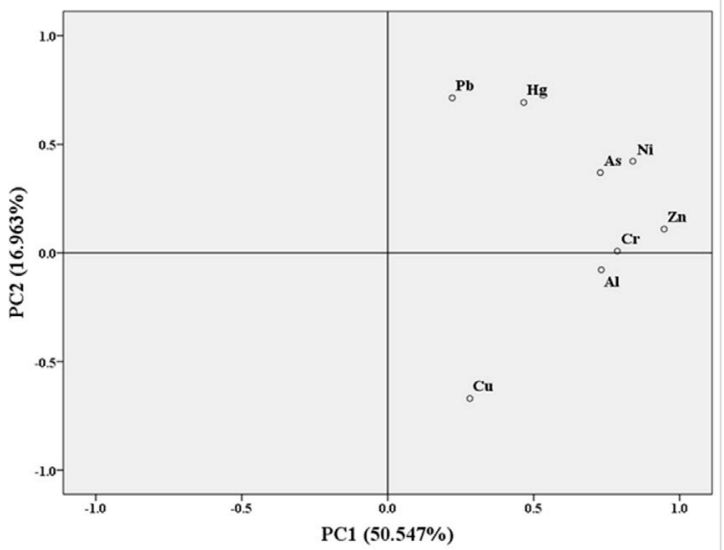

FIGURE 6 | Plots of loadings of PC1 and PC2 from principal component analysis (PCA) of sediment core SKL8-2 from Songkhla Lake. (A) The whole sediment core; (B) 63-102 cm of sediment core (1964-1982); (C) 0-63 cm of sediment core (1982-2019). the reconnection of the lake with the ocean exacerbated the complexity of material sources.

\section{Potential Ecological Assessment}

The EF and $\mathrm{I}_{\text {geo }}$ were used to quantitatively evaluate the degree of anthropogenic pollution in the sediments, and $\mathrm{Al}$ was selected as the standardized element because $\mathrm{Al}_{2} \mathrm{O}_{3}$ content was stable during the formation of the sediments and was uninfluenced by the surrounding environment (Cheevaporn et al., 1995; Srisuksawad et al., 1997). The background values of $\mathrm{Cr}, \mathrm{Ni}$, $\mathrm{Cu}, \mathrm{Zn}, \mathrm{Pb}, \mathrm{As}$, and $\mathrm{Hg}$ were 58.5, 13.0, 17.7, 35.5, 20.5, 13.0, and $0.021 \mu \mathrm{g} / \mathrm{g}$, respectively, with $\mathrm{Al}$ content of $5.15 \%$, which was determined through previous studies of Songkhla Lake and the western GoT (Ladachart et al., 2011; Liu et al., 2016).

The EF and $\mathrm{I}_{\text {geo }}$ results suggest that trace metal contamination was not severe in Songkhla Lake from 1964 onward (Figure 7). The average EF values were ranked as follows: $\mathrm{Pb}>\mathrm{Hg}>\mathrm{As}>\mathrm{Zn}$ $>\mathrm{Ni}>\mathrm{Cr}>\mathrm{Cu}$. The first five elements exhibited $\mathrm{EF}>1$, denoting slight contamination. The EF results for $\mathrm{Cr}$ and $\mathrm{Cu}$ were much lower than 1, indicating natural enrichment. The $I_{\text {geo }}$ values showed the same order as the EF index. $\mathrm{Pb}$ and $\mathrm{Hg}$ maintained the $I_{\text {geo }}>0$ throughout the core, suggesting moderate levels of contamination. The $I_{\text {geo }}$ values of $\mathrm{Zn}$ and $\mathrm{Ni}$ decreased to less than zero starting approximately in $1981 . \mathrm{Cr}$ and $\mathrm{Cu}$ showed no enrichment.

It was notable that except $\mathrm{Cr}$ and $\mathrm{Cu}$, trace metals showed contamination signals in the depth range of $15-32 \mathrm{~cm}$, corresponding to 2000-2010. This result was also supported by previous reports (Sompongchaiyakul and Sirinawin, 2007; Pradit et al., 2010; Pradit et al., 2013), which showed that concentrations of $\mathrm{As}$ and $\mathrm{Pb}$ were rising because of rapid urbanization. The outer section of Songkhla Lake receives municipal waste from two large and rapidly expanding cities, Songkhla and Hat Yai, as well as agricultural and industrial discharge transported by canals. In the 1990s, urbanization accelerated, but the first wastewater treatment plant for Hat Yai City was not built until 1999 and the treatment coverage was limited. Therefore, a large amount of untreated wastewater was still discharged into Songkhla Lake, resulting in a decline of lake water quality and environmental degradation. This poor sewage treatment had led to serious concern with regard to nutrient and metallic pollution in Songkhla Lake. In addition, expansion of Songkhla Port in 2003 (ONEP, 2005) and expansion of rubber planting in Songkhla Lake stimulated by the rising price of rubber from 2003 to 2005 may have facilitated the high enrichment in this period as well. After 2010, pollution has been kept to a low level, which was likely closely related to the concept of "man-land integration and coordinated development" in this period (Ratanachai et al., 2013).

Comparison with the ERL-ERM guideline values (Figure 8) showed that all the trace metals were under the ERM guideline values, reflecting contamination that at present is far from alarming. Nevertheless, $\mathrm{As}$ and $\mathrm{Pb}$ contents have exceeded the 
TABLE 4 | Explained data variance of the selected principal components (PCs) and their relationships with the individual sediment metals in sediment core SKL8-2.

(a) Whole sediment core PC1 (62.93\%)
PC2 (15.47\%)

\subsection{1}

0.730

0.812

0.360

0.445

$-0.141$

0.473

0.817

(c) 0-63 cm of sediment core (1982-2019)

(b) 63-102 cm of sediment core (1964-1982)

PC1 (64.06\%)

\subsection{7}

$-0.399$

0.181

0.951

0.982

0.967

0.944

0.654
PC2 (19.51\%)

\section{$-0.052$}

0.780

0.874

$-0.121$

$-0.094$

0.022

$-0.020$

0.408
PC1 (50.55\%)

PC2 (16.96\%)

$\begin{array}{ll}\mathrm{Zn} & 0.654\end{array}$

0.732
0.728
0.466
0.787
0.840
0.281
0.947
0.221

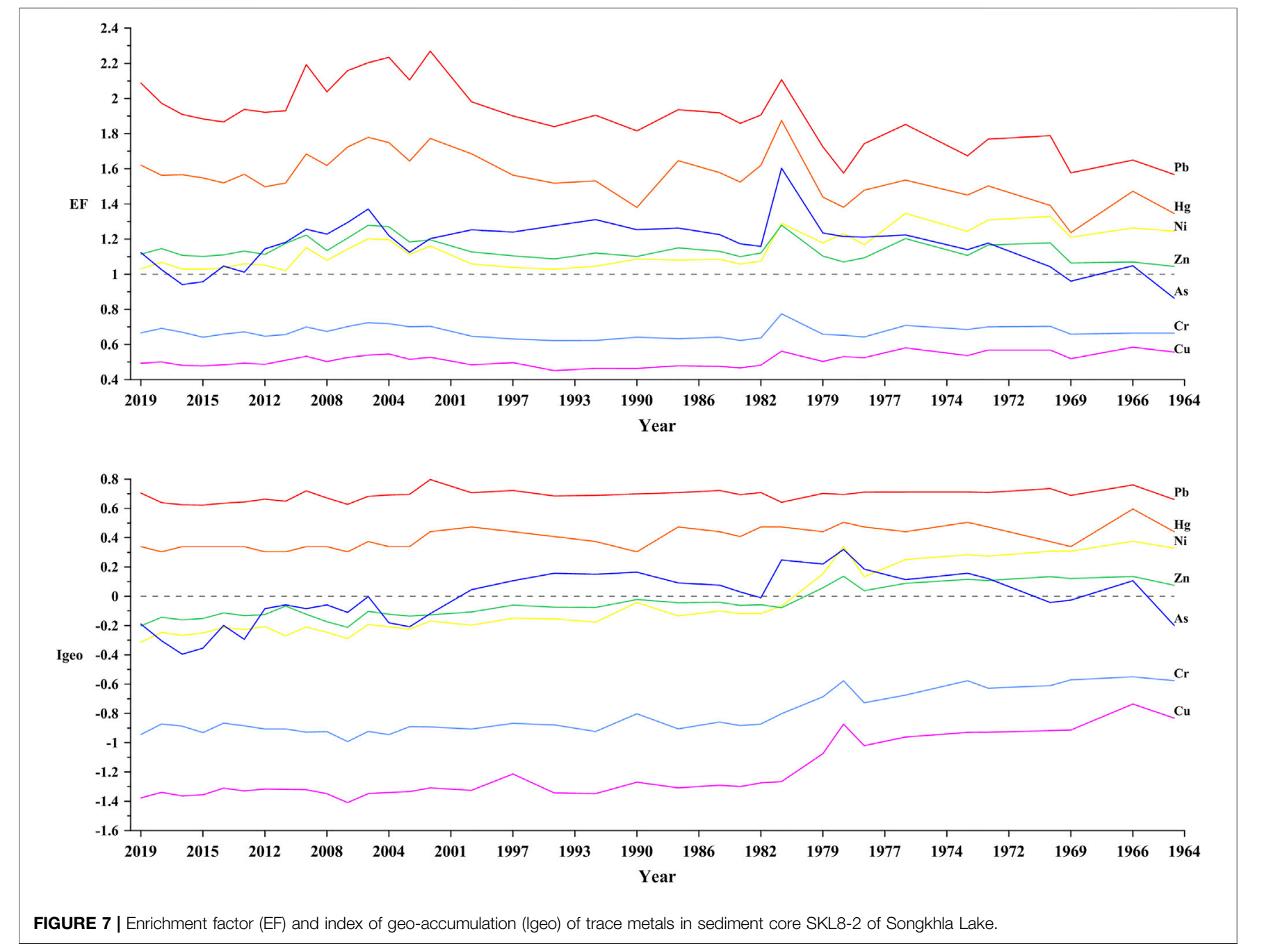

ERL threshold since 1964. Although the As content in Southeast Asia has been found to be elevated relative to global levels, which is considered to result from mining or river enrichment (Jones et al., 2008), the As and $\mathrm{Pb}$ contents in SKL8-2 were higher than the 10th percentile of the effects database and are a signal of the sustained influence of human activity, which requires attention. In addition, $\mathrm{Ni}$ exceeded the ERL limit in the period during 1964-1982. This finding further indicates terrigenous input in this period, as in nature, $\mathrm{Ni}$ mostly occurs in magnetite and sulfide deposits (Guo et al., 2019). Moreover, it was found that the concentrations of $\mathrm{Hg}, \mathrm{Cr}, \mathrm{Cu}$, and $\mathrm{Zn}$ in the sediments did not exceed the ERL limits for sediments during the entire recorded period, indicating that harmful effects on organisms would be rare. In general, these results were in agreement with the obtained $\mathrm{EF}$ and $\mathrm{I}_{\text {geo }}$ values. However, because the $\mathrm{Hg}$ content was relatively low in adjacent areas (Liu et al., 2016; Zhang et al., 2021), the results for this element showed a different contamination status. 


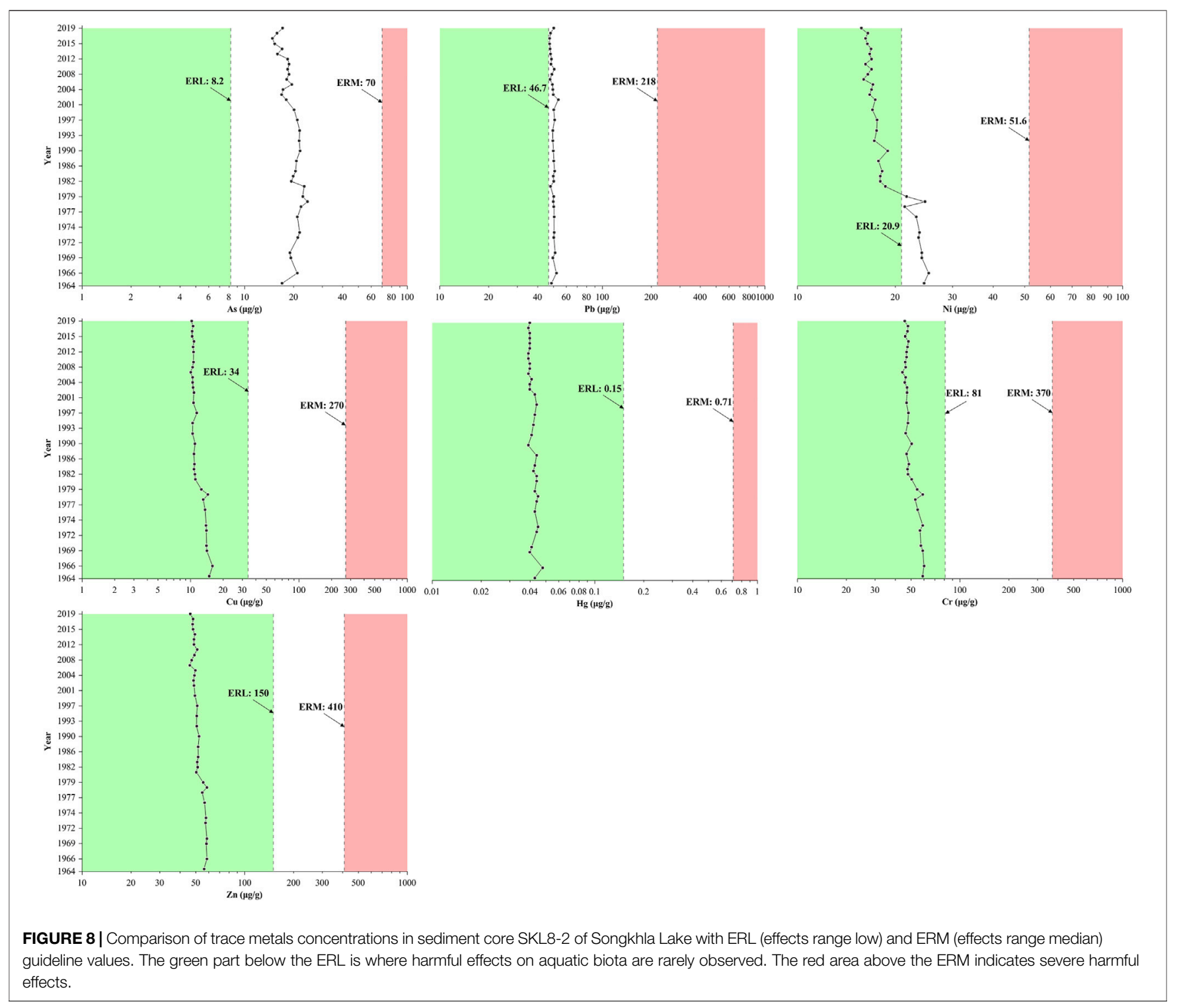

\section{CONCLUSION}

This is one of the first studies on the influences of anthropogenic activities and sea-land interactions on the modern sedimentary metal accumulation history of Songkhla Lake. We have provided a comprehensive record of the geochronology, lithology, and geochemistry of metal contamination in lake sediment core SKL8-2. The 55-year record reveals a three-stage input history of sedimentary trace metals: 1) From 1964 to 1982, the channel connecting Songkhla Lake and the GoT was closed, and there was a natural terrigenous input period with a relatively reducing environment. The deposition rate was high during this period, approximately $2.3 \pm 0.6 \mathrm{~cm} /$ year, trace metal and TOC contents were high with significant correlation, and the mean TOC/TN ratio was as high as 21.7 . The $b^{*}$ value and magnetic susceptibility were markedly low. 2) Almost all of the recorded values changed sharply in 1982. During 1982-2000, with the reopening of the channel with the GoT and the intensive development of human activities, the sources of trace metals were more complex than before and mainly came from urban wastewater, industrial effluent, and fishery discharge. 3) From 2000 to 2019, because of the rapid urban development and poor sewage treatment, contamination signals of $\mathrm{Pb}, \mathrm{Hg}, \mathrm{As}, \mathrm{Zn}$, and $\mathrm{Ni}$ emerged in the first decade, and this contamination was then alleviated with increasing environmental management efforts. Generally, based on trace metal element analysis, the sediment of Songkhla Lake was at a low contamination level, with the enrichment order $\mathrm{Pb}>$ $\mathrm{Hg}>\mathrm{As}>\mathrm{Zn}>\mathrm{Ni}>\mathrm{Cr}>\mathrm{Cu}$. Herein, $\mathrm{Pb}, \mathrm{Hg}, \mathrm{As}, \mathrm{Zn}$, and $\mathrm{Ni}$ showed moderate enrichment, while $\mathrm{Cr}$ and $\mathrm{Cu}$ exhibited no enrichment. The obtained results will be useful for future assessment of changes in the coastal environment under anthropogenic influences. Although there are signs of contamination mitigation from reduced emissions, trace metal contamination in Songkhla Lake should be closely observed in the long term, as intensified human activities and natural processes enhance trace elements release into the environment. 


\section{DATA AVAILABILITY STATEMENT}

The raw data supporting the conclusions of this article will be made available by the authors without undue reservation.

\section{AUTHOR CONTRIBUTIONS}

$\mathrm{KD}, \mathrm{SQ}$, and $\mathrm{BW}$ designed the study, synthesized, analyzed the data, and wrote the article, with contributions from all authors. NK and SK provided background information of the study area. BW, YC, XS, SL, NK, and SK helped to collect the core samples. $\mathrm{XS}, \mathrm{YC}$, and $\mathrm{KD}$ subsampled and photographed the cores. $\mathrm{KD}$ and $\mathrm{YC}$ completed all the experiments. SQ and XS analyzed the

\section{REFERENCES}

Anthony, A., Atwood, J., August, P., Byron, C., Cobb, S., Foster, C., et al. (2016). Coastal Lagoons and Climate Change: Ecological and Social Ramifications in U.S. Atlantic and Gulf Coast Ecosystems. ECOL SOC 14, 1-5. Available at: http://www.ecologyandsociety.org/vol14/iss1/art8/.

Aparecida Leite Silva, M., and Eduardo Rezende, C. (2002). Behavior of Selected Micro and Trace Elements and Organic Matter in Sediments of a Freshwater System in South-East Brazil. Sci. Total Environ. 292, 121-128. doi:10.1016/ S0048-9697(02)00034-7

Bakshi, M., Ghosh, S., Chakraborty, D., Hazra, S., and Chaudhuri, P. (2018). Assessment of Potentially Toxic Metal (PTM) Pollution in Mangrove Habitats Using Biochemical Markers: A Case Study on Avicennia officinalis L. In and Around Sundarban, India. Mar. Pollut. Bull. 133, 157-172. doi:10.1016/ j.marpolbul.2018.05.030

Barbier, E. B. (2015). Valuing the Storm Protection Service of Estuarine and Coastal Ecosystems. Ecosystem Serv. 11, 32-38. doi:10.1016/j.ecoser.2014.06.010

Bryan, G. W., and Langston, W. J. (1992). Bioavailability, Accumulation and Effects of Heavy Metals in Sediments with Special Reference to United Kingdom Estuaries: a Review. Environ. Pollut. 76, 89-131. doi:10.1016/0269-7491(92) 90099-V

Buat-Menard, P., and Chesselet, R. (1979). Variable Influence of the Atmospheric Flux on the Trace Metal Chemistry of Oceanic Suspended Matter. Earth Planet. Sci. Lett. 42, 399-411. doi:10.1016/0012-821X(79)90049-9

Cheevaporn, V., Jacinto, G. S., and San Diego-Mcglone, M. L. (1995). Heavy Metal Fluxes in Bang Pakong River Estuary, Thailand: Sedimentary vs Diffusive Fluxes. Mar. Pollut. Bull. 31, 290-294. doi:10.1016/0025-326X(95)00195-S

Crozaz, G., Picciotto, E., and De Breuck, W. (19641896-1977). Antarctic Snow Chronology with Pb210. J. Geophys. Res. 69, 2597-2604. doi:10.1029/ JZ069i012p02597

Doungsuwan, N., Ratanachai, C., Somgpongchaiyakul, P., and Sangganjanavanich, P. (2013). Impacts of the National Economic and Social Development Plan on Songkhla Lake Basin Development Thailand. Iber 12, 895. doi:10.19030/ iber.v12i8.7987

Doungsuwan, N., Ratanachai, C., Somgpongchaiyakul, P., and Sangganjanavanich, P. (2014). Sustainability Indicators for Fishery Management in Songkhla Lake, Thailand. Jsm 1, 5-12. doi:10.19030/jsm.v1i1.8388

El Zrelli, R., Yacoubi, L., Wakkaf, T., Castet, S., Grégoire, M., Mansour, L., et al. (2021). Surface Sediment Enrichment with Trace Metals in a Heavily HumanImpacted Lagoon (Bizerte Lagoon, Southern Mediterranean Sea): Spatial Distribution, Ecological Risk Assessment, and Implications for Environmental protection. Mar. Pollut. Bull. 169, 112512. doi:10.1016/j.marpolbul.2021.112512

Faremi, O. E., Sogbanmu, T. O., and Adeyemo, O. K. (2021). How Sawmill Wastes Impact Surface Water, Sediment, Macrobenthic Invertebrates, and Fish: a Case Study of the Lagos Lagoon, Okobaba Area, South-Western Nigeria. Environ. Monit. Assess. 193, 235. doi:10.1007/s10661-021-09006-0

Filgueiras, A., Lavilla, I., and Bendicho, C. (2004). Evaluation of Distribution, Mobility and Binding Behaviour of Heavy Metals in Surficial Sediments of data related to the sedimentology. $\mathrm{KD}, \mathrm{BW}$, and $\mathrm{XS}$ analyzed the data of geochemical parameters. All authors contributed to the article and approved the submitted version.

\section{ACKNOWLEDGMENTS}

The authors are grateful to Dr. Peng Cao and Yuan Dang of First Institute of Oceanography, Ministry of Natural Resources, China, for sample collection. This work was jointly supported by the National Program on Global Change and Air-Sea Interaction (GASIGEOGE-03), National Nature Science Foundation of China (U1606401), and the cooperative research program between China and Thailand "Research on Vulnerability of Coastal Zones."

Louro River (Galicia, Spain) Using Chemometric Analysis: a Case Study. Sci. Total Environ. 330, 115-129. doi:10.1016/j.scitotenv.2004.03.038

Gadkar, N. S., Nayak, G. N., and Nasnodkar, M. R. (2019). Assessment of Metal Enrichment and Bioavailability in Mangrove and Mudflat Sediments of the Tropical (Zuari) Estuary, West Coast of India. Environ. Sci. Pollut. Res. 26, 24998-25011. doi:10.1007/s11356-019-05733-7

Guo, Y., Qiao, S., Shi, X., Wu, B., Yuan, L., Ren, Y., et al. (2019). Variation Trend and Contamination Source of Heavy Metals in Sediments from Estuary Area of Bangkok Bay in the Past century. Mar. Geol. Quatern Geol. 39, 61-69. doi:10.16562/j.cnki.0256-1492.2018031901

Hinkey, L. M., and Zaidi, B. R. (2007). Differences in SEM-AVS and ERM-ERL Predictions of Sediment Impacts from Metals in Two US Virgin Islands Marinas. Mar. Pollut. Bull. 54, 180-185. doi:10.1016/j.marpolbul.2006.09.009

Hung, J.-J., Hung, C.-S., Wann, C.-K., Hung, P.-Y., and Kuo, F. (2020). Mercury Distribution and Speciation in Two Lagoons with Different Pollution and Eutrophication Conditions in Taiwan. Mar. Pollut. Bull. 156, 111096. doi:10.1016/j.marpolbul.2020.111096

Jones, H., Visoottiviseth, P., Khoda Bux, M., Földényi, R., Kováts, N., Borbély, G., et al. (2008). "Case Reports: Arsenic Pollution in Thailand, Bangladesh, and Hungary," in Reviews of Environmental Contamination Volume 197: International Perspectives on Arsenic Pollution and Remediation (New York, NYNew York: Springer), 163-187. doi:10.1007/978-0-387-79284-2_6

Jung, J.-M., Choi, K.-Y., Chung, C.-S., Kim, C.-J., and Kim, S. H. (2019). Fractionation and Risk Assessment of Metals in Sediments of an Ocean Dumping Site. Mar. Pollut. Bull. 141, 227-235. doi:10.1016/ j.marpolbul.2019.02.041

Kumblad, L., Olsson, A., Koutny, V., and Berg, H. (2001). Distribution of DDT Residues in Fish from the Songkhla Lake, Thailand. Environ. Pollut. 112, 193-200. doi:10.1016/S0269-7491(00)00118-4

Ladachart, R., Suthirat, C., Hisada, K.-i., and Charusiri, P. (2011). Distribution of Heavy Metals in Core Sediments from the Middle Part of Songkhla Lake, Southern Thailand. J. Appl. Sci. 11, 3117-3129. doi:10.3923/jas.2011.3117.3129

Laermanns, H., Pint, A., Bellanova, P., Feist, L., Wagner, B., Frank, S., et al. (2021). The Santo André Lagoon at the Atlantic Coast of Portugal - Holocene Evolution and Event History. Palaeogeogr. Palaeoclimatol. Palaeoecol. 571, 110366. doi:10.1016/j.palaeo.2021.110366

Liu, E., Shen, J., Liu, X., Zhu, Y., and Wang, S. (2006). Variation Characteristics of Heavy Metals and Nutrients in the Core Sediments of Taihu Lake and Their Pollution History. Sci. China Ser. D 49, 82-91. doi:10.1007/s11430-006-8108-6

Liu, S., Shi, X., Yang, G., Khokiattiwong, S., and Kornkanitnan, N. (2016). Concentration Distribution and Assessment of Heavy Metals in the Surface Sediments of the Western Gulf of Thailand. Environ. Earth Sci. 75, 346. doi:10.1007/s12665-016-5422-y

Long, E. R., Macdonald, D. D., Smith, S. L., and Calder, F. D. (1995). Incidence of Adverse Biological Effects within Ranges of Chemical Concentrations in marine and Estuarine Sediments. Environ. Manage. 19, 81-97. doi:10.1007/ BF02472006

Macdonald, D. D., Ingersoll, C. G., and Berger, T. A. (2000). Development and Evaluation of Consensus-Based Sediment Quality Guidelines for Freshwater 
Ecosystems. Arch. Environ. Contam. Toxicol. 39, 20-31. doi:10.1007/ s002440010075

Meyers, P. A. (1997). Organic Geochemical Proxies of Paleoceanographic, Paleolimnologic, and Paleoclimatic Processes. Org. Geochem. 27, 213-250. doi:10.1016/S0146-6380(97)00049-1

Meyers, P. A. (1994). Preservation of Elemental and Isotopic Source Identification of Sedimentary Organic Matter. Chem. Geology. 114, 289-302. doi:10.1016/ 0009-2541(94)90059-0

Müller, G. (1979). Schwermetalle in den Sedimenten des Rheins-Veränderungen seit. Umschav 79, 133-149.

Nakinchart, P., Sompongchaiyakul, P., and Sirinawin, W. (2006). Trace Metal Levels in Surficial Sediments of Songkhla Lake. Bangkok, Thailand: The Internation Conference on Hazardous Waste Management for Sustainable Future.

Newton, A., Brito, A. C., Icely, J. D., Derolez, V., Clara, I., Angus, S., et al. (2018). Assessing, Quantifying and Valuing the Ecosystem Services of Coastal Lagoons. J. Nat. Conservation 44, 50-65. doi:10.1016/j.jnc.2018.02.009

Nriagu, J. O. (1996). A History of Global Metal Pollution. Science 272, 223. doi:10.1126/science.272.5259.223

Office of Natural Resources and Environmental Policy and Planning, OPEN (2005). Master Plan for Songkhla Lake Basin Development. Hat Yai, Thailand: Final Report by Prince of Songkla University, Taksin University and Songkhla Rajabhat University.

Pedro, C. A., Santos, M. S. S., Ferreira, S. M. F., and Gonçalves, S. C. (2016). The Presence of Cadmium in the Intertidal Environments of a Moderately Impacted Coastal Lagoon in Western Portugal (Óbidos Lagoon)-Spatial and Seasonal Evaluations. Environ. Sci. Pollut. Res. 23, 1960-1969. doi:10.1007/s11356-0155847-y

Pérez-Ruzafa, A., Marcos, C., Bernal, C. M., Quintino, V., Freitas, R., Rodrigues, A. M., et al. (2012). Cymodocea Nodosa vs. Caulerpa Prolifera: Causes and Consequences of a Long Term History of Interaction in Macrophyte Meadows in the Mar Menor Coastal Lagoon (Spain, Southwestern Mediterranean). Estuarine, Coastal Shelf Sci. 110, 101-115. doi:10.1016/ j.ecss.2012.04.004

Pérez-Ruzafa, A., Mompeán, M. C., and Marcos, C. (2007). "Hydrographic, Geomorphologic and Fish Assemblage Relationships in Coastal Lagoons," in Lagoons and Coastal Wetlands in the Global Change Context: Impacts and Management Issues. Editors P. Viaroli and P. Lasserre (Campostrini: Springer Netherlands), 107-125.

Pradit, S., Pattarathomrong, M. S., and Panutrakul, S. (2013). Arsenic Cadmium and Lead Concentrations in Sediment and Biota from Songkhla Lake: A Review. Proced. - Soc. Behav. Sci. 91, 573-580. doi:10.1016/j.sbspro.2013.08.456

Pradit, S., Shazili, N. A. M., Pattaratumrong, M. S., Chotikarn, P., Kobkeatthawin, T., Yucharoen, M., et al. (2018). Accumulation of Trace Metals in Mangrove Plant Soneratia Caseoralis in Songkhla Lake, Thailand. Appl. Ecol. Env. Res. 16, 4081-4095. doi:10.15666/aeer/1604_40814095

Pradit, S., Wattayakorn, G., Angsupanich, S., Baeyens, W., and Leermakers, M. (2010). Distribution of Trace Elements in Sediments and Biota of Songkhla Lake, Southern Thailand. Water Air Soil Pollut. 206, 155-174. doi:10.1007/ s11270-009-0093-x

Qiao, S., Shi, X., Gao, J., Zhu, A., Narumol, K., Hu, L., et al. (2015). Enrichment and Bioavailability of Heavy Metals in Sediments of the Bangkok Bay. China Environ. Sci. 35, 3445-3451.

Sanchez-Cabeza, J. A., and Ruiz-Fernández, A. C. (2012). 210Pb Sediment Radiochronology: An Integrated Formulation and Classification of Dating Models. Geochimica et Cosmochimica Acta 82, 183-200. doi:10.1016/ j.gca.2010.12.024

Schmidt, H., and Reimers, C. E. (1991). The Recent History of Trace Metal Accumulation in the Santa Barbara Basin, Southern California Borderland. Estuarine, Coastal Shelf Sci. 33, 485-500. doi:10.1016/0272-7714(91)90086-Q

Sogbanmu, T. O., Nagy, E., Phillips, D. H., Arlt, V. M., Otitoloju, A. A., and Bury, N. R. (2016). Lagos Lagoon Sediment Organic Extracts and Polycyclic Aromatic Hydrocarbons Induce Embryotoxic, Teratogenic and Genotoxic Effects in Danio rerio (Zebrafish) Embryos. Environ. Sci. Pollut. Res. 23, 14489-14501. doi:10.1007/s11356-016-6490-y
Sompongchaiyakul, P., and Sirinawin, W. (2007). Arsenic, Chromium and Mercury in Surface Sediment of Songkhla Lake, Thailand. Asian J. Water Environ. Pollu. 4, 17-24.

Srisuksawad, K., Porntepkasemsan, B., Nouchpramool, S., Yamkate, P., Carpenter, R., Peterson, M. L., et al. (1997). Radionuclide Activities, Geochemistry, and Accumulation Rates of Sediments in the Gulf of Thailand. Continental Shelf Res. 17, 925-965. doi:10.1016/S0278-4343(96)00065-9

Tian, Q., Yang, T., Zhang, S., Shi, P., Zhang, J., and Fan, Z. (2011). Magnetic Susceptibility and its Environmental Significance of Lake Sediments in Tibet Plateau. Acta Sedimentol Sin 29, 143-150. doi:10.14027/j.cnki.cjxb.2011.01.011

Veiga, K., Pedro, C. A., Ferreira, S. M. F., and Gonçalves, S. C. (2019). Monitoring Metal Pollution on Coastal Lagoons Using Cerastoderma Edule-A Report from a Moderately Impacted System in Western Portugal (Óbidos Lagoon). Environ. Sci. Pollut. Res. 26, 2710-2721. doi:10.1007/s11356-018-3705-4

Velasco, A. M., Pérez-Ruzafa, A., Martínez-Paz, J. M., and Marcos, C. (2018). Ecosystem Services and Main Environmental Risks in a Coastal Lagoon (Mar Menor, Murcia, SE Spain): The Public Perception. J. Nat. Conservation 43, 180-189. doi:10.1016/j.jnc.2017.11.002

Violintzis, C., Arditsoglou, A., and Voutsa, D. (2009). Elemental Composition of Suspended Particulate Matter and Sediments in the Coastal Environment of Thermaikos Bay, Greece: Delineating the Impact of Inland Waters and Wastewaters. J. Hazard. Mater. 166, 1250-1260. doi:10.1016/ j.jhazmat.2008.12.046

Wakkaf, T., El Zrelli, R., Kedzierski, M., Balti, R., Shaiek, M., Mansour, L., et al. (2020). Characterization of Microplastics in the Surface Waters of an Urban Lagoon (Bizerte Lagoon, Southern Mediterranean Sea): Composition, Density, Distribution, and Influence of Environmental Factors. Mar. Pollut. Bull. 160, 111625. doi:10.1016/j.marpolbul.2020.111625

Yu, Z., Li, B., Li, H., Zhang, J., and Chen, J. (2020). Response of Modern Planktonic Foraminifera to the Upwelling Activity in the Southwestern South China Sea. QUATERN SCI. 40, 801-810. doi:10.11928/j.issn.1001-7410.2020.03.17

Zaharescu, D. G., Hooda, P. S., Soler, A. P., Fernandez, J., and Burghelea, C. I. (2009). Trace Metals and Their Source in the Catchment of the High Altitude Lake Respomuso, Central Pyrenees. Sci. Total Environ. 407, 3546-3553. doi:10.1016/j.scitotenv.2009.02.026

Zhang, H., Liu, S., Wu, K., Cui, J., Zhu, A., Zhang, Y., et al. (2021). Distribution and Assessment of Heavy Metal Contents in Surface Sediments of the Western Sunda Shelf. Mar. Pollut. Bull. 168, 112433. doi:10.1016/ j.marpolbul.2021.112433

Zhang, Y., and Dui, J. (2005). Background Values of Pollutants in Sediments of the South China Sea. Acta Oceanol Sin 27, 161-166. doi:10.1525/ aa.1958.60.5.02a00220

Zhou, Q., Zhang, J., Fu, J., Shi, J., and Jiang, G. (2008). Biomonitoring: An Appealing Tool for Assessment of Metal Pollution in the Aquatic Ecosystem. Analytica Chim. Acta 606, 135-150. doi:10.1016/j.aca.2007.11.018

Conflict of Interest: The authors declare that the research was conducted in the absence of any commercial or financial relationships that could be construed as a potential conflict of interest.

The handling Editor declared a past co-authorship with one of the authors (XS).

Publisher's Note: All claims expressed in this article are solely those of the authors and do not necessarily represent those of their affiliated organizations, or those of the publisher, the editors, and the reviewers. Any product that may be evaluated in this article, or claim that may be made by its manufacturer, is not guaranteed or endorsed by the publisher.

Copyright (C) 2021 Dong, Qiao, Wu, Shi, Chen, Shan, Liu, Kornkanitnan and Khokiattiwong. This is an open-access article distributed under the terms of the Creative Commons Attribution License (CC BY). The use, distribution or reproduction in other forums is permitted, provided the original author(s) and the copyright owner(s) are credited and that the original publication in this journal is cited, in accordance with accepted academic practice. No use, distribution or reproduction is permitted which does not comply with these terms. 